\title{
Effect of metal deposition on the photocatalytic activity of titania-silica for the removal of 2-propanol diluted in water
}

\author{
Reda M. Mohamed · Sayoko Shironita • \\ Kohsuke Mori · Hiromi Yamashita
}

Received: 12 January 2008/Accepted: 21 January 2008/Published online: 13 March 2009

(C) Springer Science+Business Media B.V. 2009

\begin{abstract}
The influence of transition metals, such as $\mathrm{Ag}, \mathrm{Cr}$, and $\mathrm{Co}$, on the photocatalytic properties of titania-silica $\left(\mathrm{TiO}_{2}-\mathrm{SiO}_{2}\right)$ prepared via both impregnation (imp) and photo-assisted deposition (PAD) methods has been investigated. The decomposition of 2-propanol under UV-light irradiation was used to probe the effect of transition metals deposition on the activity of titania-silica. PAD-Ag/ $/ \mathrm{TiO}_{2}-\mathrm{SiO}_{2}$ prepared by the PAD method was highly active compared to the original $\mathrm{TiO}_{2}-\mathrm{SiO}_{2}$, while imp- $\mathrm{Cr} / \mathrm{TiO}_{2}-\mathrm{SiO}_{2}$ prepared by conventional impregnation method showed a weak tendency toward the decomposition of 2-propanol.
\end{abstract}

Keywords $\mathrm{TiO}_{2}-\mathrm{SiO}_{2} \cdot$ Transition metals · Photo-assisted deposition · Impregnation · Photocatalytic activity

\section{Introduction}

Environmental pollution has increased public concern nowadays and the decontamination of polluted water and air by photocatalysis has been attracting a lot of attention for its efficiency and promising economy. Titanium dioxide in the form of anatase is the most studied photocatalyst, but it can only work under ultraviolet (UV) light because of its large band gap [1]. The use of supported titanium dioxide

\footnotetext{
R. M. Mohamed · S. Shironita $\cdot$ K. Mori · H. Yamashita $(\square)$

Division of Materials and Manufacturing Science, Graduate School of Engineering,

Osaka University, 2-1 Yamada-oka, Suita, Osaka 565-0871, Japan

e-mail: yamashita@mat.eng.osaka-u.ac.jp

R. M. Mohamed

Department of Advanced Materials, Central Metallurgical R\&D Institute,

Nanostructured Materials Lab., Helwan, Cairo 11421, Egypt
} 
has allowed the enhancement of the photodegradation rates in comparison with net titania [2, 3]. Doping titania with metal ions may enhance its photoactivity $[4,5]$ or may even enable its sensitization under visible light [5]. Titania-silica is one of the most active mixed oxide catalysts for liquid-phase oxidations; it has become an important industrial catalyst. Ever-increasing domains for clean oxidation processes with high product selectively to avoid by-products and waste formation has lead to considerable research efforts in this area. Numerous applications deal with transition metals on carrier oxides and most $3 \mathrm{~d}$ metals show some oxidation activity. However, product selectively in general is often low and homogenous reactions always compete with reactions on the catalyst surface [6-10]. A number of studies have shown that titania-silica intimate mixtures exhibit enhanced UV photocatalytic activity compared with pure titania. With this background, we undertake a target to combine the futures of intimately mixed titania-silica with the incorporation of transition metal ions. Indeed, several transition metal ions allow a band gap shift to the visible light range when impregnated on large band gap materials [11, 12]. The photodeposition process involves the reduction of metal ions by conduction band electrons, the anodic process being the oxidation of water by valance band holes. Oxidizable additives are generally added to improve the rate of deposition, such as acetate, formaldehyde, methanol, or 2-propanol, but these caused the aggregation of transition metals on the surface of the catalysts, which lead to a decrease in the activity. Our principle work in this paper focused on enhancing the photocatalytic activity. We synthesized transition metals deposited on titania-silica by $\mathrm{TM} / \mathrm{TiO}_{2^{-}}$ $\mathrm{SiO}_{2}(\mathrm{TM}=$ transition metals [Ag, $\mathrm{Co}$, and $\mathrm{Cr}$ ], present in the form of oxides) using photo-assisted deposition (PAD) and impregnation (imp) techniques. To observe the destruction of 2-propanol on a local and global scale, a photocatalyst with high reactivity under UV light is required. A number of characterizations have been carried out elaborately in attempts to obtain this goal.

\section{Experimental}

Preparation of $\mathrm{TiO}_{2}-\mathrm{SiO}_{2}$

The synthesis method is focused on the first step on the prehydrolysis of aqueous ammonia $\left(\mathrm{NH}_{4} \mathrm{OH}, 25 \%\right)$ to obtain titania-silica mixed oxides. Titanium butoxide orthotitanate (TBOT, $\geq 98 \%$ ) and tetraethyl orthosilicate (TEOS, $\geq 98 \%$ ) were selected as the source of titania and silica, respectively. Here, we give a typical procedure for the preparation of titania-silica mixed oxide containing $92.8 \mathrm{~mol} \%$ silica. Firstly, $2.25 \mathrm{ml}$ TBOT was mixed with $5.1 \mathrm{ml}$ acetylacetone and $10.0 \mathrm{ml}$ anhydrous EtOH. Secondly, $17 \mathrm{ml}$ TEOS was mixed with a solution containing $10.8 \mathrm{ml}$ distilled water, $23.9 \mathrm{ml}$ aqueous ammonia, and $20.0 \mathrm{ml}$ anhydrous EtOH under stirring. After a few minutes, the solution changed to opaque white due to the formation of dense $\mathrm{Si}$ sol. The above solutions were simultaneously added into the beaker containing $10.0 \mathrm{ml}$ anhydrous EtOH under stirring. After all operations were finished, the samples were aged for $72 \mathrm{~h}$ at room temperature. Finally, the samples obtained were evaporated to dryness, and then calcined at $823 \mathrm{~K}$ for $5 \mathrm{~h}$ in air. 
Preparation of $\mathrm{Ag}$, $\mathrm{Co}$, and $\mathrm{Cr} / \mathrm{TiO}_{2}-\mathrm{SiO}_{2}$

\section{PAD method}

The TM loaded on $\mathrm{TiO}_{2}-\mathrm{SiO}_{2}\left(\mathrm{PAD}-\mathrm{TM} / \mathrm{TiO}_{2}-\mathrm{SiO}_{2}, 4\right.$ wt $\%$ as $\mathrm{TM}$ metal, where $\mathrm{TM}$ are $\mathrm{Ag}, \mathrm{Co}$, and $\mathrm{Cr}$ ) were prepared using the PAD method: TM metals were deposited on $\mathrm{TiO}_{2}-\mathrm{SiO}_{2}$ from aqueous solution of silver nitrate, cobalt nitrate, and chromium nitrate under UV light irradiation.

\section{Impregnation method}

The TM loaded on $\mathrm{TiO}_{2}-\mathrm{SiO}_{2}$ (imp-TM/TiO$-\mathrm{TiO}_{2}, 4$ wt $\%$ as TM) were prepared using the impregnation method. The TM were deposited by the impregnation of $\mathrm{TiO}_{2^{-}}$ $\mathrm{SiO}_{2}$ with aqueous solution of silver nitrate, cobalt nitrate, and chromium nitrate. The samples were dried at $378 \mathrm{~K}$ and reduced by $\mathrm{H}_{2}\left(20 \mathrm{ml} \mathrm{min}^{-1}\right)$ at $473 \mathrm{~K}$ for $2 \mathrm{~h}$.

\section{Characterization techniques}

X-ray diffraction (XRD) was used to identify the crystal phases of the prepared catalyst. These studies were performed by using a Rigaku RINT-2000 wide-angle $\mathrm{X}$-ray diffractometer system using $\mathrm{Cu} \mathrm{K} \alpha$ radiation to the assess the crystallinity of the catalyst and a power of $40 \mathrm{kV} \times 30 \mathrm{~mA}$. The intensity data were collected at $298 \mathrm{~K}$. TM/titania-silica were ran from 20 to $80^{\circ}(2 \theta)$. The powders were characterized by a UV-vis spectrophotometer (Shimadzu UV-2450) at $295 \mathrm{~K}$ in the range $200-800 \mathrm{~nm} . \mathrm{BaSO}_{4}$ was used as the standard in these measurements. The morphology and particle size of the prepared samples were examined via a transmission electron microscope (TEM, Hitachi H-9500 operated at $300 \mathrm{kV}$ ).

Photocatalytic reactions by $\mathrm{TM} / \mathrm{TiO}_{2}-\mathrm{SiO}_{2}$

The photocatalytic activity of $\mathrm{TM} / \mathrm{TiO}_{2}-\mathrm{SiO}_{2}$ was evaluated by the photodegradation of 2-propanol aqueous solution. All photocatalytic reactions were performed under UV light irradiation with continuous oxygen and maintaining constant mechanical stirring for $1 \mathrm{~h}$ under a dark atmosphere. Twenty-five milliliters of 2-propanol $\left(2.6 \times 10^{-3} \mathrm{~mol} \mathrm{dm}^{-3}\right)$ was mixed with $50 \mathrm{mg}$ of calcined catalysts in a quartz cell. The UV light was provided by a $100 \mathrm{~W}$ high-pressure mercury lamp (wavelength $\lambda>250 \mathrm{~nm}$ ). The catalysts and solution were separated by filtration and then the resulting solution was analyzed by gas chromatography (GC, GC-14B, Shimadzu).

\section{Results and discussion}

\section{Catalyst characterization}

The XRD analysis was employed to characterize the crystallinity of the catalysts showing a number of trends. First, XRD patterns of each parent $\mathrm{TiO}_{2}-\mathrm{SiO}_{2}$ and 
transition metal-doped $\mathrm{TiO}_{2}-\mathrm{SiO}_{2}$ nanoparticles prepared by the imp and PAD methods are presented in Figs. 1 and 2, respectively. The results show that the main structural characteristic phases of $\mathrm{TiO}_{2}-\mathrm{SiO}_{2}$ and all transition metal-doped $\mathrm{TiO}_{2}$ $\mathrm{SiO}_{2}$ is the pure anatase phase, which seems that the titania anatase phase structure remained after applying the PAD and imp methods. The second part of XRD analysis was performed in order to assess the crystallinity of the transition metal loaded onto $\mathrm{TiO}_{2}-\mathrm{SiO}_{2}$, which showed that our samples exhibited no peak from the transition metal; this is probably attributed to the low transition metal doping content (ca. $4 \mathrm{wt} \%$ ). Moreover, the data may imply that the TM was well dispersed within the $\mathrm{TiO}_{2}-\mathrm{SiO}_{2}$ phase.

The UV-vis spectra of the catalyst in the range $200-800 \mathrm{~nm}$ are shown in Fig. 3. As shown in Fig. 3A, the $\mathrm{TiO}_{2}-\mathrm{SiO}_{2}$ exhibits absorption in the UV light range, while the $\mathrm{PAD}-\mathrm{Ag} / \mathrm{TiO}_{2}-\mathrm{SiO}_{2}$ and imp- $\mathrm{Ag} / \mathrm{TiO}_{2}-\mathrm{SiO}_{2}$ catalysts exhibit absorption in the visible light range as well as in the UV light range. Also, as shown in Fig. 3A, the PAD-Ag/ $\mathrm{TiO}_{2}-\mathrm{SiO}_{2}$ and imp- $\mathrm{Ag} / \mathrm{TiO}_{2}-\mathrm{SiO}_{2}$ catalysts exhibit no intense absorption band due to the $\mathrm{Ag}^{+}$ions at around $190 \mathrm{~nm}$, while the broad absorption band due to the $\mathrm{Ag}_{\mathrm{n}}^{0}$ and $\mathrm{Ag}_{\mathrm{n}}^{+}$clusters appear above $250 \mathrm{~nm}$, indicating that the reduction and aggregation of $\mathrm{Ag}^{+}$ions have occurred [13]. In the case of PAD-Ag/TiO $-\mathrm{SiO}_{2}$, the intensity of this broad absorption band is smaller than that of imp- $\mathrm{Ag} / \mathrm{TiO}_{2}-\mathrm{SiO}_{2}$, suggesting that the aggregation in the case of imp- $\mathrm{Ag} / \mathrm{TiO}_{2}-\mathrm{SiO}_{2}$ is higher than that of $\mathrm{PAD}-\mathrm{Ag} / \mathrm{TiO} \mathrm{O}_{2}-\mathrm{SiO}_{2}$.

Fig. 3B shows the UV-vis spectra of the $\mathrm{TiO}_{2}-\mathrm{SiO}_{2}, \mathrm{PAD}-\mathrm{Co} / \mathrm{TiO}_{2}-\mathrm{SiO}_{2}$, and imp-Co/ $\mathrm{TiO}_{2}-\mathrm{SiO}_{2}$ catalysts. As shown in Fig. 3B, the $\mathrm{TiO}_{2}-\mathrm{SiO}_{2}$ exhibits absorption in the UV light range, while the $\mathrm{PAD}-\mathrm{Co} / \mathrm{TiO}_{2}-\mathrm{SiO}_{2}$ and imp-Co/ $\mathrm{TiO}_{2}-\mathrm{SiO}_{2}$ catalysts exhibit absorption in the UV light at high wavelength. Figure $3 \mathrm{C}$ shows the UV-vis spectra of the $\mathrm{TiO}_{2}-\mathrm{SiO}_{2}, \mathrm{PAD}-\mathrm{Cr} / \mathrm{TiO}_{2}-\mathrm{SiO}_{2}$, and imp-Cr/ $/ \mathrm{TiO}_{2}-\mathrm{SiO}_{2}$ catalysts. As shown in Fig. $3 \mathrm{C}$, the $\mathrm{TiO}_{2}-\mathrm{SiO}_{2}$ exhibit absorption in the UV light range, which the $\mathrm{PAD}-\mathrm{Cr} / \mathrm{TiO}{ }_{2}-\mathrm{SiO}_{2}$ and $\mathrm{imp}-\mathrm{Cr} / \mathrm{TiO}{ }_{2}-\mathrm{SiO}_{2}$ catalysts exhibit absorption in the UV light at high wavelength.

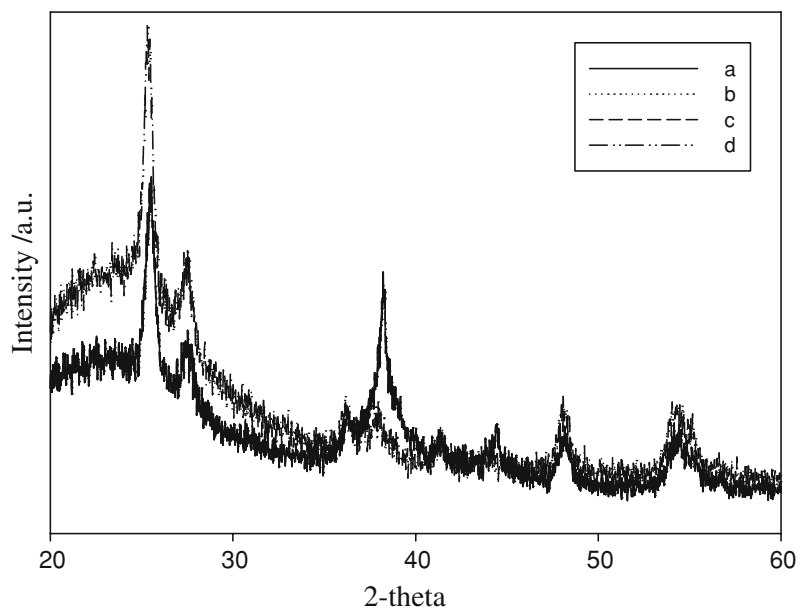

Fig. 1 X-ray diffraction (XRD) patterns of: $a \mathrm{TiO}_{2}-\mathrm{SiO}_{2}, b \mathrm{PAD}-\mathrm{Ag} / \mathrm{TiO}_{2}-\mathrm{SiO}_{2}, c$ PAD-Co/TiO${ }_{2}-\mathrm{SiO}_{2}$, and $d \mathrm{PAD}-\mathrm{Cr} / \mathrm{TiO}_{2}-\mathrm{SiO}_{2}$ 


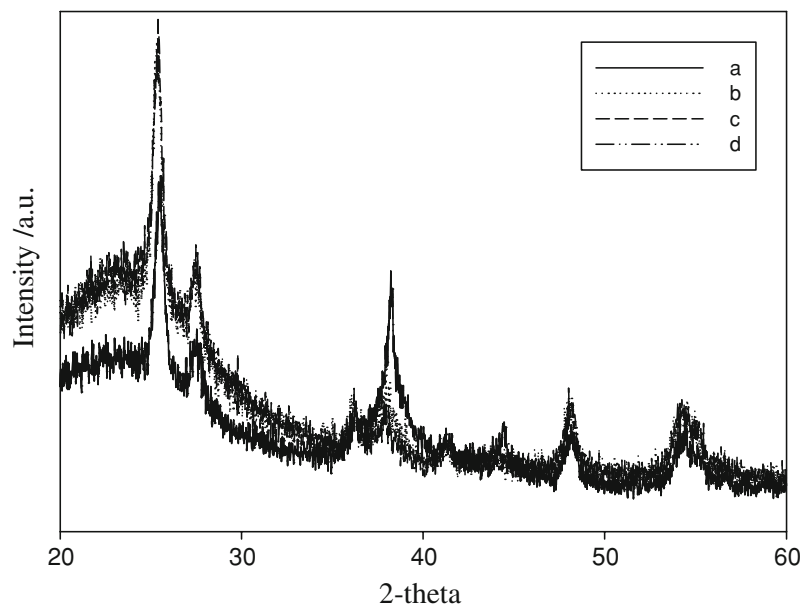

Fig. $2 \mathrm{XRD}$ patterns of: $a \mathrm{TiO}_{2}-\mathrm{SiO}_{2}, b \mathrm{imp}-\mathrm{Ag} / \mathrm{TiO}_{2}-\mathrm{SiO}_{2}, c \mathrm{imp}-\mathrm{Co} / \mathrm{TiO}_{2}-\mathrm{SiO}_{2}$, and $d \mathrm{imp}-\mathrm{Cr} / \mathrm{TiO}{ }_{2}-\mathrm{SiO}_{2}$
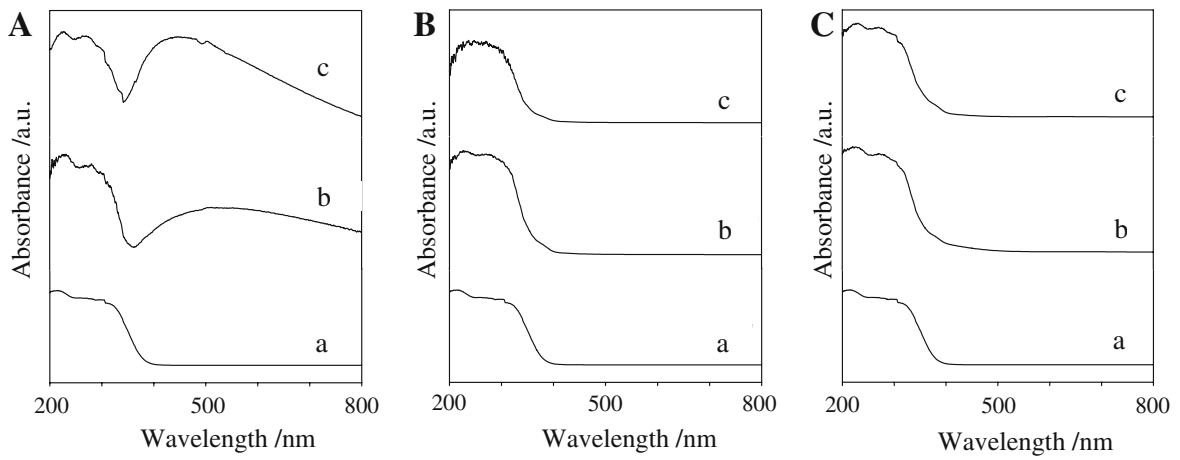

Fig. 3 A UV-vis spectra of: $a \mathrm{TiO}_{2}-\mathrm{SiO}_{2}, b$ PAD-Ag/TiO $-\mathrm{SiO}_{2}$, and $c$ imp-Ag/TiO $-\mathrm{SiO}_{2}$. B UV-vis spectra of: $a \mathrm{TiO}_{2}-\mathrm{SiO}_{2}, b \mathrm{PAD}-\mathrm{Co} / \mathrm{TiO}_{2}-\mathrm{SiO}_{2}$, and $c$ imp-Co/TiO ${ }_{2}-\mathrm{SiO}_{2}$. C UV-vis spectra of: $a \mathrm{TiO}_{2-}$ $\mathrm{SiO}_{2}, b \mathrm{PAD}-\mathrm{Cr} / \mathrm{TiO}_{2}-\mathrm{SiO}_{2}$, and $c$ imp-Cr/TiO $-\mathrm{SiO}_{2}$

The TEM image of the PAD-Ag/TiO $2-\mathrm{SiO}_{2}, \mathrm{imp}-\mathrm{Ag} / \mathrm{TiO}_{2}-\mathrm{SiO}_{2}, \mathrm{PAD}-\mathrm{Co} / \mathrm{TiO}_{2}$ $\mathrm{SiO}_{2}$, imp-Co/TiO $2-\mathrm{SiO}_{2}, \mathrm{PAD}-\mathrm{Cr} / \mathrm{TiO}_{2}-\mathrm{SiO}_{2}$, and imp-Cr/TiO${ }_{2}-\mathrm{SiO}_{2}$ catalysts are shown in Fig. 4. The results show that the particle size of $\mathrm{Ag}$ which is prepared by the PAD method is the smallest particle size. Also the order of the particle size in case of the PAD method is as follows: PAD-Ag $<$ PAD-Co $<$ PAD-Cr, and in case of the impregnation method is as follows: imp-Ag $<$ imp-Co $<$ imp-Cr. This means that the particle size of the deposited metals depends on the preparation methods, and the PAD method gives the smaller particle size.

Photocatalytic degradation of 2-propanol

The photocatalytic degradation of 2-propanol is used as a probe reaction to test the catalytic activity of the catalysts. It is divided into two sections as follows. 


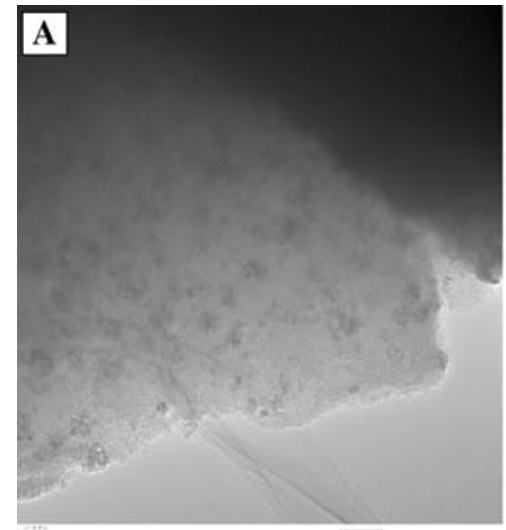

$10 \overline{\mathrm{nm}}$

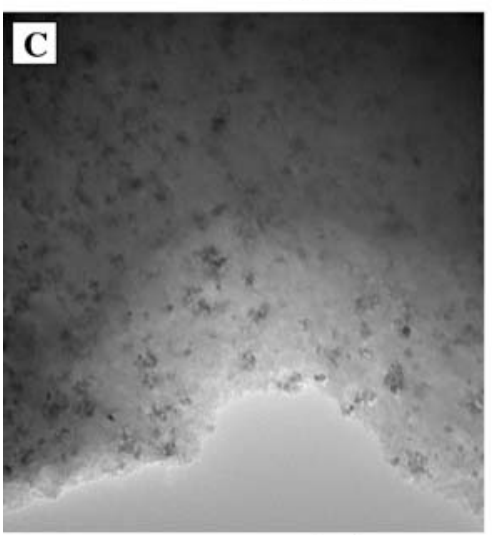

$10 \overline{\mathrm{nm}}$

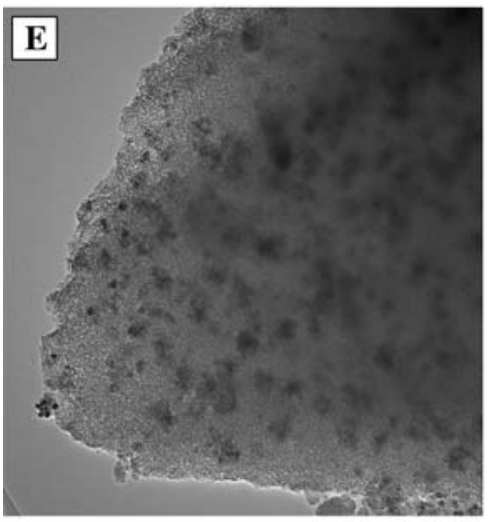

$10 \overline{\mathrm{nm}}$

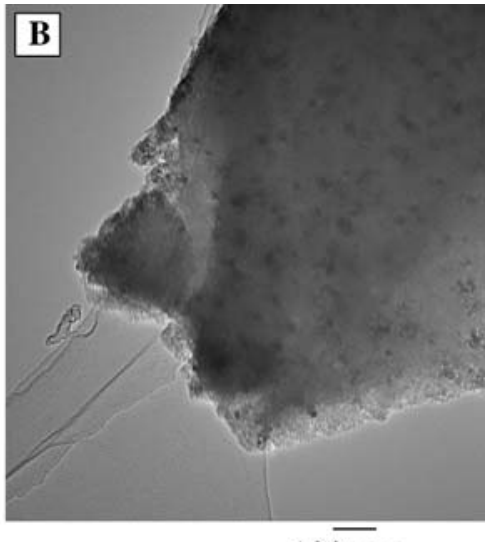

$100 \mathrm{~nm}$

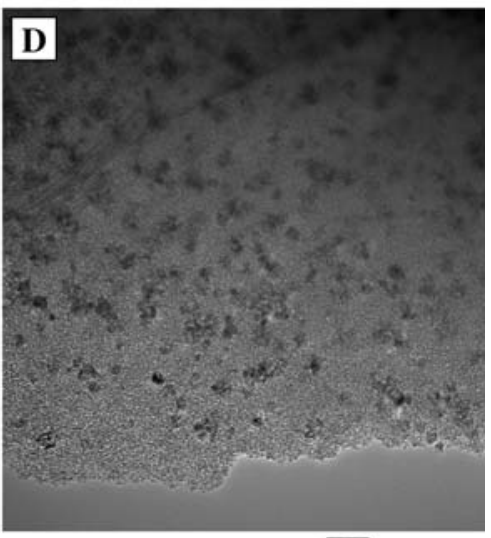

$10 \overline{\mathrm{nm}}$

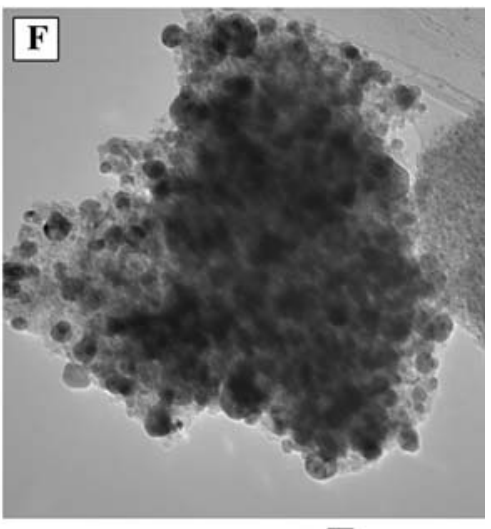

$100 \overline{\mathrm{nm}}$

Fig. 4 Transmission electron microscope (TEM) images of: A PAD-Ag/TiO ${ }_{2}-\mathrm{SiO}_{2}, \mathbf{B}$ imp- $\mathrm{Ag} / \mathrm{TiO}{ }_{2}-$ $\mathrm{SiO}_{2}, \mathbf{C ~ P A D}-\mathrm{Co} / \mathrm{TiO}_{2}-\mathrm{SiO}_{2}, \mathbf{D} \mathrm{imp}-\mathrm{Co} / \mathrm{TiO}_{2}-\mathrm{SiO}_{2}, \mathbf{E} \mathrm{PAD}-\mathrm{Cr} / \mathrm{TiO}_{2}-\mathrm{SiO}_{2}, \mathbf{F} \mathrm{imp}-\mathrm{Cr} / \mathrm{TiO}_{2}-\mathrm{SiO}_{2}$ catalysts after $\mathrm{H}_{2}$ treatment at $473 \mathrm{~K}$ 


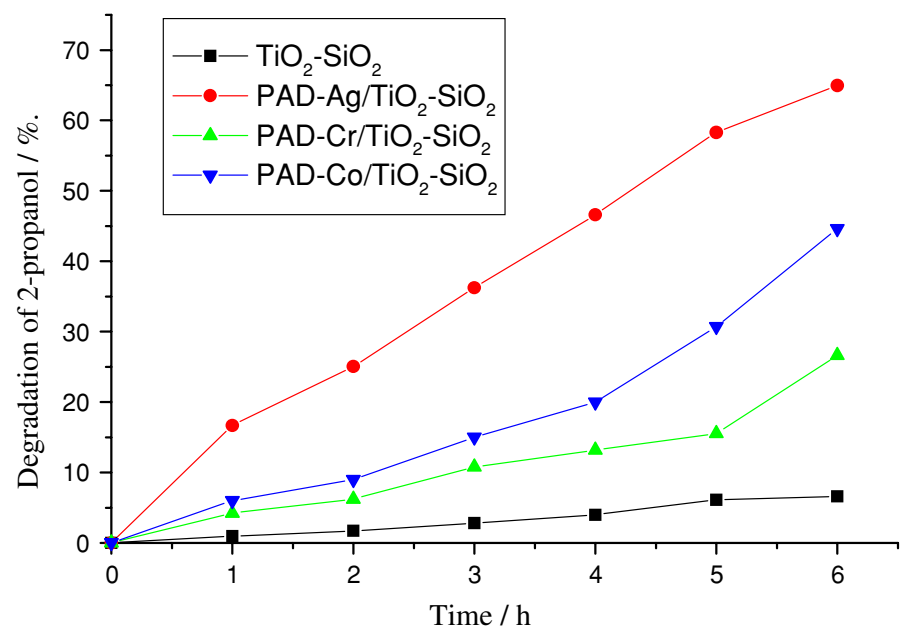

Fig. 5 Photocatalytic degradation of 2-propanol diluted in water on $\mathrm{TiO}_{2}-\mathrm{SiO}_{2}$ and different transition metals loaded by the photo-assisted deposition (PAD) method

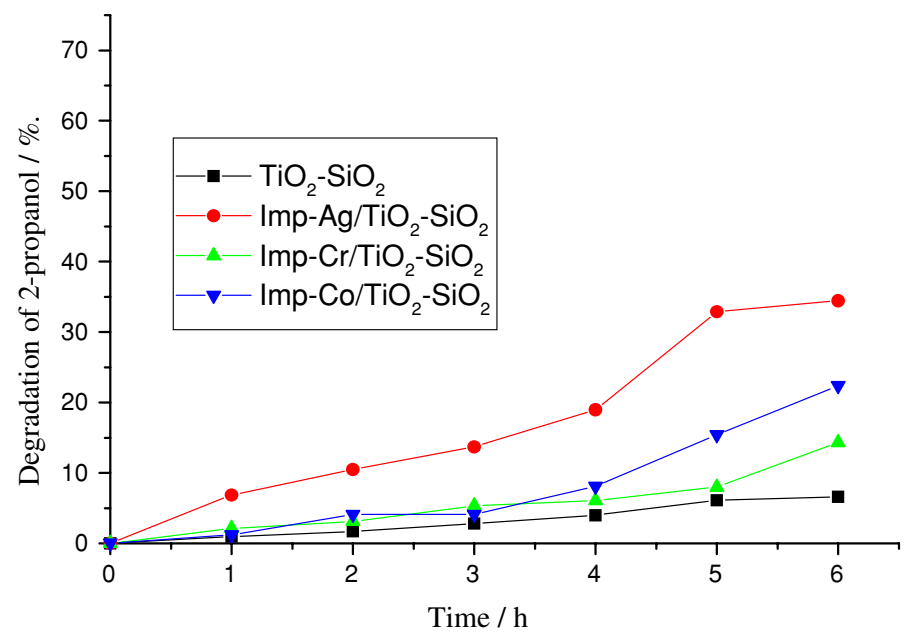

Fig. 6 Photocatalytic degradation of 2-propanol diluted in water on $\mathrm{TiO}_{2}-\mathrm{SiO}_{2}$ and different transition metals loaded by impregnation

The effect of PAD-Ag/TiO $2-\mathrm{SiO}_{2}, \mathrm{imp}-\mathrm{Ag} / \mathrm{TiO}_{2}-\mathrm{SiO}_{2}, \mathrm{PAD}-\mathrm{Co} / \mathrm{TiO}_{2}-\mathrm{SiO}_{2}$, imp$\mathrm{Co} / \mathrm{TiO}_{2}-\mathrm{SiO}_{2}, \mathrm{PAD}-\mathrm{Cr} / \mathrm{TiO}{ }_{2}-\mathrm{SiO}_{2}$, and imp-Cr/TiO $-\mathrm{SiO}_{2}$ catalysts on the photocatalytic oxidation of 2-propanol after $6 \mathrm{~h}$ at room temperature using $2.6 \times$ $10^{-3} \mathrm{~mol} \mathrm{dm}^{-3}, 25 \mathrm{ml}$, of the 2-propanol and $50 \mathrm{mg}$ catalyst are shown in Figs. 5 and 6. The data demonstrate that the photocatalytic efficiency of the $\mathrm{PAD}-\mathrm{Ag} / \mathrm{TiO}{ }_{2}-\mathrm{SiO}_{2}$ is higher than that of $\mathrm{PAD}-\mathrm{Co} / \mathrm{TiO}_{2}-\mathrm{SiO}_{2}$ and $\mathrm{PAD}-\mathrm{Cr} / \mathrm{TiO}_{2}-\mathrm{SiO}_{2}$. In addition to this, the effect of the impregnation method on photocatalytic activities is also investigated systematically as follows: the photocatalytic activity of imp- $\mathrm{Ag} / \mathrm{TiO} \mathrm{O}_{2}-\mathrm{SiO}_{2}$ 
is higher than that of imp- $\mathrm{Co} / \mathrm{TiO}_{2}-\mathrm{SiO}_{2}$ and imp-Cr/TiO $-\mathrm{SiO}_{2}$. This can be attributed to the small particle size of $\mathrm{Ag}$ in comparison to those of $\mathrm{Co}$ and $\mathrm{Cr}$.

From the results noted, the photocatalytic activity of $\mathrm{PAD}-\mathrm{Ag} / \mathrm{TiO}_{2}-\mathrm{SiO}_{2}$ is higher than that of imp- $\mathrm{Ag} / \mathrm{TiO}_{2}-\mathrm{SiO}_{2}$. This is attributed to the aggregation of $\mathrm{Ag}$ in the case when PAD-Ag/TiO $-\mathrm{SiO}_{2}$ is smaller than that of imp- $\mathrm{Ag} / \mathrm{TiO}_{2}-\mathrm{SiO}_{2}$, which is confirmed by UV-vis and TEM results and is in agreement with an earlier report [14]. The photocatalytic activity of $\mathrm{PAD}-\mathrm{Cr} / \mathrm{TiO}_{2}-\mathrm{SiO}_{2}$ is higher than that of imp$\mathrm{Cr} / \mathrm{TiO}_{2}-\mathrm{SiO}_{2}$.

\section{Conclusion}

Different transition metals ( $\mathrm{Ag}, \mathrm{Co}$, and $\mathrm{Cr}$ ) deposited on $\mathrm{TiO}_{2}-\mathrm{SiO}_{2}$ was synthesized by photo-assisted deposition (PAD) and impregnation (imp) methods. Using the PAD method in the deposition of transition metals afforded well controlled size and good dispersion on tetrahedrally coordinated Ti-oxide of the support. Also, the direct interaction between nano-sized transition metals and the photo-excited tetrahedrally coordinated Ti-oxide realized by the PAD method under UV-light irradiation gives one the possibility to design unique and active nano-sized metal catalysts. The characterization results showed enhancement of the photocatalytic activity. Such photocatalytic activity of $\mathrm{TM} / \mathrm{TiO}_{2}-\mathrm{SiO}_{2}$ in UV light was tested for the degradation of 2-propanol. The PAD-Ag/TiO $-\mathrm{SiO}_{2}$ catalyst exhibited the highest photocatalytic activity and smallest particle size with high dispersion.

\section{References}

1. M.R. Hoffmann, S.T. Martin, W.Y. Choi, D.W. Bahnemann, Chem. Rev. 95, 69 (1995)

2. L. Davydov, E.P. Reddy, P. France, P.G. Smirniotis, J. Catal. 203, 157 (2001)

3. Y.M. Xu, C.H. Langford, J. Phys. Chem. B 101, 3115 (1997)

4. W. Choi, A. Termin, M.R. Hoffmann, J. Phys. Chem. 98, 13669 (1994)

5. N. Serpone, D. Lawless, J. Didier, J.M. Herrmann, Langmuir 10, 643 (1994)

6. M. Dusi, T. Mallat, A. Baiker, Catal. Rev. Sci. Eng. 42, 213 (2000)

7. R.A. Sheldon, M. Wallau, I. Arends, U. Schuchardt, Acc. Chem. Res. 31, 485 (1998)

8. H. Kochkar, F. Figueras, J. Catal. 171, 420 (1997)

9. M. Taramasso, G. Perego and B. Notari, US Patent 4, 410, 501 (1983)

10. C. Beck, T. Mallat, A. Baiker, Catal. Lett. 75, 131 (2001)

11. A.D. Paola, L. Palmisano, M. Schiavello, K. Uosaki, S. Ikeda, B. Ohtani, J. Phys. Chem. B 106, 637 (2002)

12. C.H. Langford, Y. Xu, Langmuir 17, 897 (2001)

13. W.-S. Ju, M. Matsuoka, K. Lino, H. Yamashita, M. Anpo, J. Phys. Chem. B 108, 2128 (2004)

14. M.-W. Xu, S.-J. Bao, X.-G. Zhang, Mater. Lett. 59, 2194 (2005) 